\title{
INFESTATION OF FROGHOPPER NYMPHS CHANGES THE AMOUNTS OF TOTAL PHENOLICS IN SUGARCANE
}

\author{
Rafael José Navas da Silva ${ }^{1}$; Eduardo Rossini Guimarães ${ }^{1}$; José Francisco Garcia ${ }^{3}$; Paulo Sérgio \\ Machado Botelho'; Maria Inês Tiraboschi Ferro'; Miguel Angelo Mutton²; Márcia Justino \\ Rossini Mutton ${ }^{1 *}$ \\ ${ }^{1}$ UNESP/FCAV - Depto. de Tecnologia - Via de Acesso Prof. Paulo Donato Castellane, S/N, C.P. 14884-900 - \\ Jaboticabal, SP - Brasil. \\ ${ }^{2} U N E S P / F C A V$ - Depto. de Produção Vegetal. \\ ${ }^{3}$ USP/ESALQ - Depto. de Entomologia, Fitopatologia e Zoologia Agrícola, C.P. 09 - 13418-900 - Piracicaba, SP - \\ Brasil. \\ ${ }^{4}$ UFSCar/CCA - Depto. de Biotecnologia Vegetal, Rod. Anhanguera, km 174 - 13600-970 - Araras, SP - \\ Brasil. \\ *Corresponding author <mjrmut@fcav.unesp.br>
}

ABSTRACT: The increased rate of sugarcane harvest without previous burn has provided a very favorable environment to the froghopper Mahanarva fimbriolata (Stal, 1854), with high moisture and low temperature variation. Few works have studied the response of sugarcane to this pest, so little is known about resistant cultivars. Plant phenolics are widely studied compounds because of their known antiherbivore effect. This research aims to determine if the attack of $M$. fimbriolata nymphs stimulates the accumulation of total phenolics in sugarcane. The experiment was carried out in greenhouse and arranged in completely randomized design, in a $3 \times 2 \times 4$ factorial with three replications. Second instar nymphs of $M$. fimbriolata were infested at the following rates: control, 2-4 and 4-8 nymphs per pot (first-second infestations, respectively). Pots were covered with nylon net and monitored daily to isolate the effect of leaf sucking adults. Leaf and root samples were collected and kept frozen in liquid nitrogen until analyses. Infested plants showed higher levels of phenolics in both root and leaf tissues. In roots, the cultivar SP80-1816 accumulated more phenolic compounds in response to the infestation of $M$. fimbriolata. On the other hand, higher levels were found in leaves and roots of control plants of SP86-42, which might be an indication of a non-preference mechanism. The increase of total phenolics in sugarcane infested with root-sucking froghopper nymphs does not seem to be useful to detect the resistance to this pest.

Key words: Saccharum spp., phenolic compounds, secondary metabolism, plant-insect interaction

\section{INFESTAÇÃO DE NINFAS DE CIGARRINHAS-DAS-RAÍZES ALTERA A QUANTIDADE DE COMPOSTOS FENÓLICOS EM CANA-DE-AÇÚCAR}

RESUMO: Com a intensificação da colheita mecanizada da cana-de-açúcar sem queima da palhada, a cigarrinha-das-raízes Mahanarva fimbriolata (Stal, 1854) tornou-se uma das principais pragas da cultura, favorecida pelas condições de umidade e baixa variação de temperatura do solo. Poucos trabalhos são dedicados ao estudo da resposta da planta ao ataque deste inseto, dificultando o conhecimento de cultivares resistentes. Os compostos fenólicos são muito estudados por sua ação anti-herbivoria. A presente pesquisa foi conduzida com o objetivo de verificar se o ataque de ninfas de $M$. fimbriolata induz alterações na quantidade de fenóis totais em cana-de-açúcar. $O$ experimento foi instalado em casa de vegetação, com condições de temperatura e umidade controladas, com delineamento inteiramente casualizado em esquema fatorial $3 \times 2 \times 4$ e três repetições. Ninfas de segundo ínstar de $M$. fimbriolata foram inoculadas no sistema radicular das plantas, nos níveis: controle, 2-4 e 4-8 ninfas por vaso (primeira-segunda infestação, respectivamente). Os vasos foram cobertos com tela de nylon para isolar o efeito dos adultos, que eram mortos nos monitoramentos diários. Folhas e raízes foram coletadas e congeladas em nitrogênio líquido até a realização das análises. Plantas atacadas por ninfas de $M$. fimbriolata apresentaram maiores teores de fenóis totais em raízes e folhas. A cultivar SP80-1816 apresentou-se mais responsiva ao ataque das ninfas em raízes. A cultivar SP86-42 apresentou maiores teores de fenóis em raízes e folhas de plantas controle, podendo ser um indicativo da nãopreferência dos insetos por esta variedade. O teor de compostos fenólicos parece não ser um bom marcador para identificar genótipos de cana-de-açúcar resistentes a ninfas de M. fimbriolata.

Palavras-chave: Saccharum spp., fenóis totais, metabolismo secundário, interação planta-inseto

Sci. Agric. (Piracicaba, Braz.), v.62, n.6, p.543-546, Nov./Dec. 2005 


\section{INTRODUCTION}

The froghopper Mahanarva fimbriolata (Stal, 1854) has become one of the major pests of sugarcane crops in Brazil with the increase of harvesting without previous burn. The litter left on the field, with high moisture and low temperature variation, provides favorable environment to the species.

Froghopper infestations are positively correlated with high precipitation and soil temperatures, which in Sao Paulo state take place from November to April (Gallo et al., 2002). Froghopper nymphs feed mostly on root xylem, possibly causing water and nutrient deficiency and general metabolic disturbs in plants (Gallo et al., 2002; Hagley \& Blackman, 1966).

The resistance of plants to insect pests involves many chemical factors and may occur under any situation or be induced (Nutt et al., 2004). Phenolics, a group of secondary metabolites, play very important roles in plants such as protection against environmental stresses (Hahlbrock \& Scheel, 1989). In regard to insect-pests, phenolics act as digestion inhibitors, and producing free radicals (Appel, 1993).

The chlorogenic acid, a cinnamic acid derivative, and the rutin, a flavonoid glycoside, are models in the study plant antiherbivore defense because of their wide occurrence among higher plants and well-known toxicity to insect pests. Oxidation of chlorogenic acid yields quinones that covalently bind to proteins and consequently limit their availability as nutrients (Friedman, 1997). This may also result in the formation of reactive oxygen species (superoxide radical and $\mathrm{H}_{2} \mathrm{O}_{2}$ ), which damage nutrient molecules such as lipids, proteins, and nucleic acids (Appel, 1993; Summers \& Felton, 1994).

The characterization of the types and amounts of phenolics in response to herbivory is important to understand the interaction plant-herbivore, and is useful to develop new control strategies and to plant breeding programs focusing on resistance. To date, very little is known about the physiological response of sugarcane to $M$. fimbriolata. In this research, we determine how sugarcane responds to the infestation of froghopper nymphs, in terms of leaf and root total phenolics.

\section{MATERIAL AND METHODS}

Trials were set in greenhouse under controlled conditions ( $\mathrm{T}=22$ to $33^{\circ} \mathrm{C}$; $\mathrm{RH}=50$ to $60 \%$ ). Two, onebud seed pieces were planted in $15-\mathrm{L}$ plastic pots $(30 \mathrm{~cm}$ in diameter) and watered daily to field capacity. To provide a moist environment with stable temperature to the froghopper nymphs, each pot was covered with $65 \mathrm{~g}$ of sugarcane straw (corresponding $9 \mathrm{t} \mathrm{ha}^{-1}$ ) 18 days before the first infestation.
The experiment was set in a $3 \times 2 \times 4$ factorial scheme, completely randomized design $(n=3)$, with infestation levels, sugarcane cultivars and sampling times as factors. Treatments within each factor were as follows:

- Infestation levels: 0-0, 2-4 and 4-8 nymphs per pot (firstsecond infestation, respectively).

- Sugarcane cultivars: SP 80-1816 (susceptible) and SP 86-42 (resistant, data not shown).

- Sampling times: 74, 101, 130, and 154 days after planting (dap), corresponding to 0 and 28 days after the first infestation and 16 and 31 days after the second infestation, respectively.

Data were submitted to ANOVA and means compared by Tukey test $(\alpha=0.1)$ using the software SAS (SAS Institute, 1999).

\section{Production of nymphs and infestation}

Froghopper nymphs were produced as recommended by Garcia (2002). The infestation of second instar nymphs was performed with the help of a \#4 brush at 73 and 123 dap, at rates of 0 (control), 2 and 4 nymphs per pot, and 0,4 and 8 nymphs per pot, respectively. To isolate the effect of leaf-sucking adults, pots were covered with a 100-mesh nylon net right after the first infestation. Starting ten days after the first infestation, pots were monitored daily and all adults found were immediatelly killed.

\section{Extraction and analyses of phenolic compounds}

Leaves +1 (Küijper system, Dillewijn, 1952) lacking the midribs were immediately frozen in liquid $\mathrm{N}_{2}$ after harvesting. Samples of younger roots $(10 \mathrm{~g})$ were gently washed and carefully dried in paper towels before freezing.

Leaf and root aliquots $(4 \mathrm{~g})$ were cut into $50 \mathrm{~mm}$ pieces and stirred with $30 \mathrm{~mL}$ of acidified methanol $(1 \%$ $\mathrm{HCl})$ for $12 \mathrm{~h}$ at $4^{\circ} \mathrm{C}$. The extract was filtered in Whatman paper \# 42 and diluted $10 \times$ and $15 \times$ (extraction solution) for leaf and root samples, respectively. Samples of $500 \mu \mathrm{L}$ were added to $2.5 \mathrm{~mL}$ of the Folin-Ciocalteau's reagent (diluted $10 \times$ in distilled water) and $2 \mathrm{~mL}$ of $\mathrm{Na}_{2} \mathrm{CO}_{3}(7.5 \% \mathrm{w} / \mathrm{v})$. The mixture rested in warm water bath $\left(45^{\circ} \mathrm{C}\right)$ for 15 minutes. The absorbance at $765 \mathrm{~nm}$ was then read in a Shimadzu UV mini 1240 spectrophotometer. The rate of total phenolics was expressed in catechin equivalents per gram of fresh weight.

\section{RESULTS AND DISCUSSION}

The infestation with froghopper nymphs stimulated the production of phenolic compounds in root tissues (Figures 1.1, 1.2, 1.3). The level of phenolics was significantly higher in attacked plants (Figure 1.1). This 
result is consistent with previous experiments, which found increased phenolic production response in other plant species driven by pest infestations (Bi et al., 1997; Ghumare \& Mukherjee, 2003).

Changes in the amounts and types of phenolics occur in both resistant and susceptible sugarcane geno-
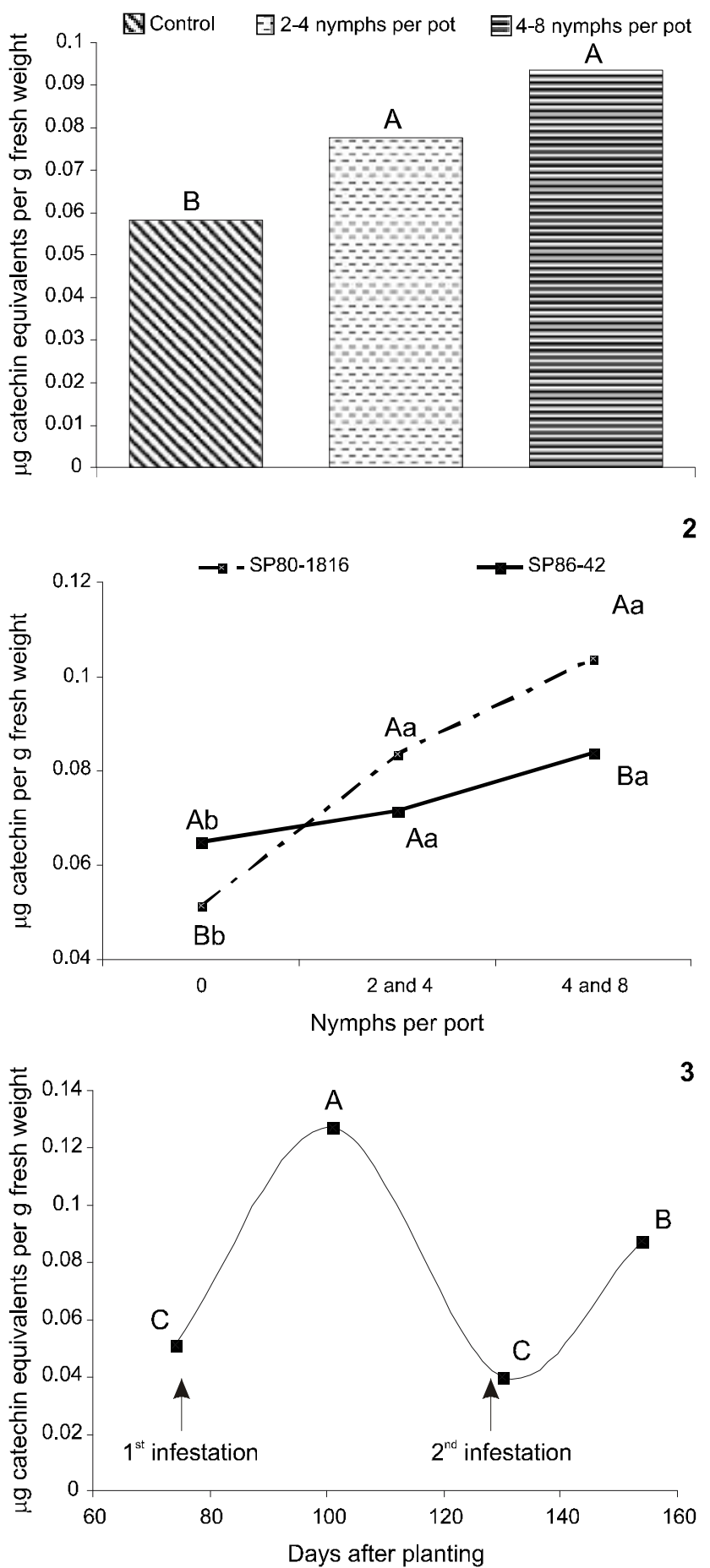

Figure 1 - Accumulation of phenolic compounds in root tissues; 1 - Effect of infestation levels; 2 - Effect of the cultivars within infestation levels; 3 - Effect over the samplings. In 1.2, capital letters compare means vertically and lower case letters compare means horizontally. types in response to whitegrubs (Coleoptera: Scarabaeidae) (Nutt et al., 2004). In this study, the susceptible cultivar SP80-1816 has shown to be more responsive (Figure 1.2), an indication that increasing phenolic production is related to the stress caused by froghopper damage. During plant cell death, the vacuole content with many phenolics and proteinases is released. When these proteinases break down other proteins, they release the aromatic amino acids phenylalanine, tyrosine and tryptophane, which account for some of the phenolics content (Buchanan et al., 2000). Since SP86-42 showed fewer symptoms, it is likely that nymphs did not develop as well as in the cultivar SP80-1816, maybe due to non-phenolics-based response of SP86-42.

Plants accumulating higher rates of phenolics tend to inhibit herbivore development (Ghumare \& Mukherjee, 2003; Beninger et al., 2004). However, in this study, more stress symptoms were found in the cultivar accumulating higher amounts of phenolic compounds (SP801816). The autumnal moth (Epirrita autumnata) larvae developed better in intact branches of previously-attacked mountain birch (Betula pubescens) leaves, indicating systemic-induced susceptibility (Lempa et al., 2004).

In roots, the highest rates of phenolics were found in samples taken at 28 and 31 days after the first and second infestation, respectively, when nymphs were reaching the adult stage. The decrease from the second to the third sampling may be due to the 22-day period in which plants were kept free of $M$. fimbriolata stress, because nymphs from the first infestation had become adults. The low rate found at the third sampling may be explained by the fact that the second infestation had just been performed, and the voracity of second instar nymphs is low (Horsfield, 1978). Nutt et al. (2004) reported inducible changes in the amounts and types of phenolics in sugarcane roots infested with whitegrubs. These changes do not follow a pattern, and are therefore useless as markers in breeding programs.

The rate of leaf phenolics was also higher in infested plants. However, the level 2-4 nymphs per pot was not statistically different from control plants, showing that the response is not as expressive as in root tissues (Figure 2.1). The increased production in leaves of infested plants is an evidence of a systemic response of sugarcane to the root sucking nymphs.

The sugarcane cultivar SP86-42 produced higher amounts of phenolic compounds in leaves, but there was no correlation with the infestation levels (Figure 2.1). Since in field conditions this cultivar is not often infested, its naturally higher amount of phenolics may be responsible for a non-preference mechanism.

The levels of phenolic compounds decreased over time in leaf tissues (Figure 2.3). Since this behavior was observed in both control and infested plants, it seems to be a result of metabolic changes during plant aging. Simi- 
lar results in tissues that were not attacked by Phytophthora capsici in Capsicum annuum were reported by Gayoso et al., (2004). This is an indication that the rate of total phenolics in leaf tissues is not very useful to detect the responses of plants to $M$. fimbriolata nymphs infesting roots.

Even though there is an increase in the amount of total phenolics in sugarcane infested with root-sucking nymphs of $M$. fimbriolata, this parameter does not
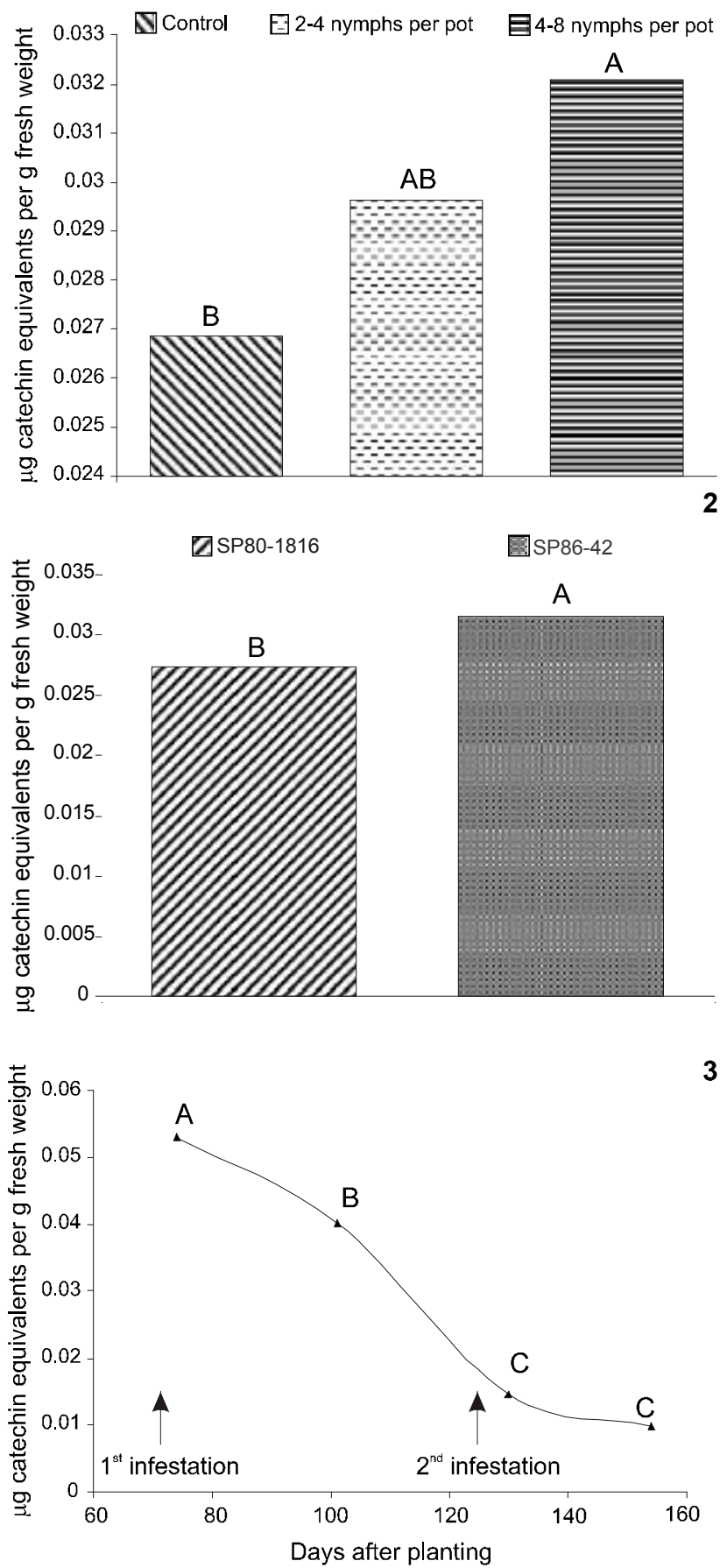

Figure 2 - Accumulation of phenolic compounds in leaf tissues; 1 Effect of infestation levels; 2 - Effect of the cultivars; 3 Effect over the samplings. seem to be useful to detect resistance in breeding programs, which is accordance to Nutt et al. (2004). Further characterization of the types of phenolic compounds that are induced might indicate if there is a phenolic-based resistance to sucking insects.

\section{REFERENCES}

APPEL, H.M. Phenolics in ecological interactions: the importance of oxidation. Journal of Chemical Ecology, v.19, p.1521-1552, 1993.

BENINGER, C.W.; ABOU-ZAID, M.M.; KISTNER, A.L.; HALLETT, R.H.; IQBAL, M.J.; GRODZINSKI, B.; HALL, J.C. A flavanone and two phenolic acids from Chrysanthemum morifolium with phytotoxic and insect growth regulating activity. Journal of Chemical Ecology, v.30, p.589-606, 2004.

BI, J.L.; FELTON, G.W.; MURPHY, J.B.; HOWLES, P.A.; DIXON, R.A.; LAMB, C.J. Do plant phenolics confer resistance to specialist and generalist insect herbivores? Journal of Agricultural and Food Chemistry, v.45, p.4500-4504, 1997

BUCHANAN, B.; GRUISSEM, W.; JONES, R. Biochemistry and molecular biology of plants. Rockville: American Society of Plant Physiologists, 2000. 1367p.

DILLEWIJN, C. van. Botany of sugar cane. Waltham: Chronica Botanica, 1952. 371p

FRIEDMAN, M. Chemistry, biochemistry, and dietary role of potato polyphenols. A review. Journal of Agriculture and Food Chemistry, v. 45, p. $1523-1540,1997$.

GALLO, D.; NAKANO, O.; SILVEIRA NETO, S. Manual de entomologia agrícola. 3 ed. Piracicaba: FEALQ, 2002. 920p.

GARCIA, J.F. Técnica de criação e tabela de vida de Mahanarva fimbriolata (Stal, 1854) (Hemiptera: Cercopidae). Piracicaba: USP/ESALQ, 2002. 59p. (Dissertação - Mestrado). Disponível: http://www.teses.usp.br/teses/ disponiveis/11/11146/tde-12022003-152242/publico/jose.pdf.

GAYOSO, C.; POMAR, F.; MERINO, F.; BERNAL, M.A. Oxidative metabolism and phenolic compounds in Capsicum annuum L. var. annuum infected by Phytophthora capsici Leon. Scientia Horticulturae, v.102, p.1-13, 2004.

GHUMARE, S.S.; MUKHERJEE, S.N. Performance of Spodoptera litura Fabricius on different host plants: influence of nitrogen and total phenolics of plants and mid-gut esterase activity of the insect. Indian Journal of Experimental Biology, v.41, p.895-899, 2003.

HAGLEY, E.A.C.; BLACKMAN, J.A. Site of feeding of the sugarcane froghopper, Aeneolamia varia saccharina (Homoptera:Cercopidae). Annals of the Entomological Society of America, v.59, p.1289-1291, 1966.

HAHLBROCK, K.; SCHEEL, D. Physiology and molecular biology of phenylpropanoid metabolism. Annual Review in Plant Physiology and Plant Molecular Biology, v.40, p.347-369, 1989.

HORSFIELD, D. Evidence for xylem feeding by Philaenus spumarius L. (Homoptera: Cercopidae). Entomologia Experimentalis et Applicata, v.24, p.95-99, 1978

LEMPA, K.; AGRAWAL, A.A.; SALMINEN, J.P.; TURUNEN, T.; OSSIPOV, V.; OSSIPOVA, S.; HAUKIOJA, E.; PIHLAJA, K. Rapid herbivoreinduced changes in mountain birch phenolics and nutritive compounds and their effects on performance of the major defoliator Epirrita autumnata. Journal of Chemical Ecology, v.320, p.303-321, 2004.

NUTT, K.A.; O'SHEA, M.G.; ALLSOPP, P.G. Feeding by sugarcane whitegrubs induces changes in the types and amounts of phenolics in the roots of sugarcane. Environmental and Experimental Botany, v.51, p.155-165, 2004.

SAS INSTITUTE. SAS/STAT User's Guide, Version 6, Cary, 1999.

SUMMERS, C.B.; FELTON, G.W. Prooxidant effects of phenolic acids on the generalist herbivore Helicoverpa zea (Lepidoptera: Noctuidae): potential mode of action for phenolic compounds in plant anti-herbivore chemistry. Insect Biochemistry and Molecular Biology, v.24, p.943953, 1994

Received January 17,2005

Accepted September 02, 2005 